\title{
Problem of Financial Resource Mobilization for Local Development: The Case of Single Land Tax (CFU) in the Governorate of Conakry Guinea
}

\author{
Diallo Mamadou Saliou Kokouma (Corresponding author) \\ School of Economic and Management (International Trade) \\ Southeast University, Nanjing \\ No.2 Sipailou, Nanjing 210096, China \\ E-mail:salitadiallo26@yahoo.com \\ Huang Kai \\ College of International Studies \\ Southeast University, Nanjing China \\ E-mail:hkhw@seu.edu.cn
}

Received: December 23, 2011

Accepted: January 25, $2012 \quad$ Published: April 15, 2012

doi:10.5430/ijfr.v3n2p35

URL: http://dx.doi.org/10.5430/ijfr.v3n2p35

\begin{abstract}
This paper examines the challenges of mobilizing financial resources for local development in Conakry, the capital city of the Republic of Guinea, as observed in a study that took place between $27^{\text {th }}$ February and $26^{\text {th }}$ July, 2007. It aims to identify problems and obstacles to the mobilization of sources by consultation of management and archives work planning, developing interview guides and sampling, fieldwork, analyzing data collected and interpretation of the results. By using a survey, the study adopted a participatory approach based on dialogue and interview of the involved actors such as the governor; management officials at the municipal level, the national tax directorate, the tax department of the city and the taxpayers. The paper concludes by suggesting some policy recommendations and appropriate strategies that can be implemented to overcome the challenges identified and consequently increase the level of tax collections and enhance good management of expenditures.
\end{abstract}

Keywords: Local Development, Financial Resource, Property Tax, Mobilization, Contribution Foncière Unique(CFU)

\section{Introduction}

For a harmonious and sustainable development, economics are absolutely pedestal to politics. As such, there is the need for grassroots democracy to underpin the progressive movement of decentralization by ensuring that the mobilization of local financial resources leads to the economic recovery of communities. The implementation of decentralization policies involves the sharing of responsibilities between central and local authority that promotes a better allocation of financial resources between the two.

Underdeveloped countries, in their decentralization policies instituted since the 90 s, have encouraged the mobilization of domestic resources as a critical stage of the process of economic and social development.

Municipalities and rural development communities or CRD (Communauté Rurale de Développement) are an example of a decentralized local feature in developing economies using taxes and financial services to build their financial independence and allow them to be full participants in the management and development of urban and rural regions. In the current context, all stakeholders are involved in the management and planning of public affairs with local communities at the base in an all inclusive participatory bottom-up process. This involvement ensures financial autonomy which supports decentralization and development through the mobilization of local financial resources- a condition for the success of the decentralization policy.

The increase in urban and rural population that accompanies densification and unprecedented overcrowding is causing a deep degradation of the urban environment and rural development. This is reflected in particular by the failure to see the presence of the material comfort, the emergence of health problems and housing, an increase of crime rate, all of which 
are likely to undermine the social equilibrium of CRD and municipalities. For example, the population of Conakry, the capital of Guinea, rose from 1,092,436 inhabitants in 1998 to 1,931,184 in 2008 reflecting a growth rate of 2.63\%.

Under decentralized planning, it has become abundantly clear that local finances are central to the issue of financing of local sustainable development and good governance in the fight against poverty. Given this experience, do communities now have sufficient financial capacity to undertake the tasks assigned to them? Do they have the effectiveness and efficiency in their tax regime and other local products that they can use to mobilize resources capable of making local investments that are self-financed? If this is not the case, what are the difficulties in mobilizing resources that must be overcome?

In relation to the issues raised above, we consider it appropriate to propose a strategy to be put in place to overcome all the factors of social, economic and political nature and the consequences that are manifested in the populations of these communities vis-à-vis their resources.

\section{Literature Review on Local Development}

According to J. Mercoiret (2006), local development is a dynamic process of mobilizing resources and energies to improve local living conditions, resources and potential for creation, accumulation and wealth distribution in a territory controlled by gradually all its inhabitants. However, local development doses not mean that there is no help from outside and as such, other authors have expanded the scope of local development. If the local community is left by itself, it is generally unable to effectively fight against the process of decay and take the path of development Bernard Vachon (2001). A combination of the two levels of leadership, both local and central, is essential for development.

According to Paul Houee (2003), the logic of local development corresponds to a double logic. First, a bottom-up approach which should be dynamic and made of the expression of needs and application of initiatives of local groups rooted in the territory, history and shared values. The preferred needs are fairly comprehensive and should be realized using a strategy that involves mobilization of actors and their potential common projects. On the other hand is a top-down approach, from the state and its components, made of the policies. It gives priority to sectoral or thematic programs, equipment or structures, the administrative relationship between the relays and the recognized representatives of the population.

These two logics, ascending and descending, must constantly cross, to return information and dialogue: actors need to know the local administrative and financial arrangements in order appropriately rely on them and adapt. The government has to realize that they need bottom-up local initiatives. Local authorities are usually at the crossroads of these two approaches.

According AFD (2001) ( Agence Française de Développement), local development has three main issues. Firstly, is to meet the needs of people placed in positions The development is conceived more as a process imposed from the top passive actors who simply receive information, services or equipment identified by officials or by experts who claim to know their needs better than the people themselves. The collective responsibility of the actors at the base in recognition of their development strategy means the success of this strategy will depend on the efficient allocation of resources and aims to strengthen ownership of development projects and thereby improve the maintenance and sustainability of actions, infrastructure and equipment.

Secondly, is to ensure a coherent economic and social development, negotiated and sustainable across a territory. The creation and implementation of local authorities with elected councils and members as part of decentralization policy aim to encourage the emergence of local public spaces in which one can develop local civic and collective ownership of public goods. They help facilitate the negotiation between immediate needs and long-term challenges that participatory approaches sometimes do not take into account.

Thirdly, the link between local development and sectoral programs requires, on the part of the state, the definition of sectoral policies and laying down guidelines to ensure uniform standards are applicable throughout the territory and a redefinition, sector by sector, the roles and responsibilities of different actors that are involved. These include the central government, decentralized services of the state, grassroots communities and local authorities with an emphasis on local actors whenever they appear more relevant and have the capacity.

According to Issa Sorgho (2006), originating a local development initiative will be unsuccessful with a situation that does not meet the needs and aspirations of individuals or groups of individuals within the community. In general, the triggering event of the awareness of the problem has one or the other of two sources.

(i) One that is external to the community, in this case, the community is not the initiator of the collective consciousness. The triggering event is caused by an external force. Those initiators then express their opinions and try to gather the 
population around them to strengthen their position. It is a response to a situation where the solution lies with an authority outside the group concerned. In this case, when the community is in a position of reaction, it adopts a passive mode of action.

(ii) An internal origin within the community, the community or a small group within the community becomes aware of some problems that undermine the public or certain signs of crisis. In the second scenario, the triggering event will follow an active mode. The community will be master of choice and the conduct of interventions appropriate to the situation. The two main mechanisms of this mode are: peoples' participation, in other words, people's access to decision-making spheres, and planning, in other words, the definition of clear objectives and means to achieve them. The prospect that opens in the latter case can only be that of the coordinated action, carried out by people who feel involved, motivated, and able to initiate action and support a development project. This is the ideal way of access to local development.

\section{Materials and Methods}

\subsection{Materials}

The Republic of Guinea, a West African country, took its independence from France in 1958. It is from the community of West African States (ECOWAS) and is located between $7^{\circ} .04$ and $12^{\circ} .51$ of the attitude North $7^{\circ} .30$ and $15^{\circ} .10$ of West longitude on the Atlantic coast of West Africa. It shares its borders in the north-west with Guinea Bissau and the Atlantic Ocean $(364 \mathrm{~km}$ of coast), in the south with Sierra Leone and Liberia, with Senegal in the North, Mali in the northeast and Ivory Coast in the east. Guinea has a total area of $245857 \mathrm{~km}^{2} ; 9,690,222$ inhabitants and a population density of 39.4 inhabitants per $\mathrm{km}^{2}$; a growth rate of $2.63 \%$ with $66 \%$ living in rural areas, and a tropical climate $24 \mathrm{c}{ }^{\circ}$ to $28 \mathrm{c}^{\circ}$.

Conakry, the capital of the Republic of Guinea is located on the peninsula of Kaloum in coastal south-west of Guinea Maritime region between $9^{\circ} .30$ and $9^{\circ} 40$ of the north latitude, between $13^{\circ} .31$ and $13^{\circ} .42$ of the west longitude. It is bordered to the north and south by the Atlantic Ocean. Conakry stretches $36 \mathrm{~km}$ north-south and is 4 to $6 \mathrm{~km}$ wide, with a tropical climate and rainfall reaching $4000 \mathrm{~mm}$ per annum. The year is divided into two seasons and the average wind speed is $2.9 \mathrm{~m} / \mathrm{s}$ with a temperature difference from $28 \mathrm{c}^{\circ}$ to $25 \mathrm{c}^{\circ}$ in May and August. The colonial city of Conakry and basic business center of the country has evolved in size and population. A few years after Independence, Conakry was divided into three prefectures: Conakry1; Conakry2 and Conakry3.

The central government was decentralized in 1992 which led to Conakry being redistributed into five municipalities: Dixinn; Kaloum; Matam; Matoto, and Ratoma. The organization of the five_municipalities of Conakry is as defined by regulations to comply with the order N19/PRG/SGG/90 on training, organization and operation of municipalities' replica of Guinea and decree N91/142/PRG / SGG / May 241992 on general principles and operation of communal services. The city has a cosmopolitan population estimated (2008) 1,931,184 inhabitants.

Conakry is the capital of political and socioeconomic activities. Such activities are varied and include agro-business that is mostly characterized by the practice of traditional techniques with low yields. They are mainly based on crops (eggplant, tomatoes, peppers, carrots, onions, potatoes, rice, corn etc.) And traditional farming methods with the exception of a few farms that are located in a small scale farming of sheep, goats and pigs in peripheral areas. Fishing consists of both artisan canoe fishery and industrial trawlers. The handicraft sector is composed of shoemakers, draperies, blacksmiths and saponification, among others.

Trade in Conakry is mainly based on economic liberalism or private investment. The main business centers include the harbor, the airport and shopping malls in Madina, Kaloum, Niger and Matam. Products are both locally made and imported. Traders sell a large variety of commodities that range from rice (staple food) to other cereals, vegetables, plus electrical appliances. Conakry has the most developed industrial corporations of the country which manufacture both food and building materials. These include: the Bonagui, Topaz; Metal Guinea; SOBRAGUI; Soguifab and Soap Alpha. Conakry also has remarkable potential as a source of foreign exchange earnings due to its tourist attractions but this has remained unexploited. (See map in the note)

\subsection{Methods}

\subsubsection{Methodology}

The methodology of the study consisted of the identification of taxpayers (taxable population/tax base) which is a fundamental component to identify all the agents operating within the framework of the exercise of their profession, the tax assessment, liquidation of the tax base, tax collection and remittance. 
The study also involved the consultation of documents and archives following the reference articles (original budget, administrative account, the General Tax Code, the taxpayer's guide, financial analysis of the city of Conakry and municipalities) and web sites. An appraisal guide, a document containing questions which were addressed to each target group (elected local leaders on tax services; regulators; enumerators, collection agents, taxpayers) was also developed as a data collection tool.

The data collection was based on a participatory approach and was performed according to the investigation in the field, which was done through channels such as individual interviews, focus on groups, and the mass media. The mobilization of financial receipts studied how this process can be illustrated by sampling data collected in tax revenues of the CFU of the governor and the five municipalities during the years of the study i.e. 2003, 2004, 2005 and 2006. Given the extent and importance of staffing in the municipalities, the information was collected at the level of resource persons and companies. Finally, data analysis was conducted, both qualitatively and quantitatively, based on a representative sample.

\subsubsection{Single land tax (CFU)}

This is a synthetic tax resulting from the merger of the land tax and tax on building properties. Potentially, this tax is an important source of finance for the local government when viewed from the perspective of the rapid urbanization but its performance did not follow the dynamic context as expected. Improving the collection deserves to be central concerns of revenue mobilization at the local level. Formerly shared by the state and local governments; the (CFU) has been totally reassigned from the city to municipalities, namely the tax paid by corporations to the city and that of individuals for municipalities. Given that (CFU) is one of the taxes that affect most of the household income, it is quite permissible for a portion of the proceeds are reinvested for locations of tax bases. If neighborhoods are closely associated to the identification and recovery of (CFU), their attitude and contribution will necessarily grow. In fact, the property tax is a tax difficult to mobilize and is unpopular due to the unwillingness of owners to pay it. Therefore the involvement of neighborhoods in the mobilization of this tax will contribute to the improvement of the collections. Thus, the reliability of this intervention will be the retrocession with a portion of the property tax rate, which will be about $10 \%$, reserved for residential quarters.

Imposed by the Finance Act 1998, the CFU replaced property taxes that included: the (CFU) on the built and non-built heritage, the housing tax, tax on property income. Taxable properties (CFU moral) are buildings (houses, manufacturing plants, factories, and retail facilities); industrial facilities fixed for a permanency; the vacant land for commercial use (sites, places of departure of goods, warehouses etc.). Taxable persons (CFU physical) include owners of properties or building; usufructuaries (tenants); landlords or dealers (long lease). Exempted from the tax are properties belonging to the state and local governments when assigned to a public utility or buildings and sites used for religious worship, buildings used for preschool and school when they are built by private developers (LF-Finance Law 1998, Article 19), public buildings used as preschool, school and property belonging to diplomatic and consular representations in the context of reciprocity (LF 1999, Article17).

The rate of CFU is $10 \%$ of the annual value for owner-occupied buildings and $15 \%$ of the annual rental for rental properties. These rates apply on the gross rental income, no deduction or allowance charge is authorized. The rental value is determined using authentic leases, by comparison or by way of direct assessment. The taxable amount determined through direct assessment (method used for construction of equipment for factories and businesses) is calculated as follows: market value, $70 \%$ of the cost of buildings and equipment; rental value, $10 \%$ of market value and single land tax, $10 \%$ of the rental value. In other words (CFU) is equal to $0.7 \%$ of the total cost of building construction, equipment and facilities when the taxable rental value is determined by this method of assessment.

The modes of payment of the CFU are: withholding for buildings leased by the state, legal persons, local communities, NGOs and credit institutions (landlords) conceding that rents net of tax and; payment directly by taxpayers (payment of solidarity between the landlord and the tenant for life of buildings). The payment must be made before $30^{\text {th }} \mathrm{June}$ of each year. It is stated that the owners must attach all the necessary statements otherwise the tax authority will assess by comparison or by direct assessment. Since $1^{\text {st }}$ January 2001, public schools with an industrial or commercial presence, local and foreign NGOs, international agencies and diplomatic representations and consular institutions and similar bodies must make a withholding tax on the rent of leased buildings for the purposes of the chancery or as a residence. It is the same for estate agents and other property manager intermediaries. A deduction equal to $15 \%$ of the gross rent is payable to the collector of taxes in the fifteen days following month. Withholding is deducted from the rent paid to the owner (LF 2000 Art. 17and 18).

Distribution of proceeds from the single land tax (CFU). According to the under Article 273 of the Tax Code, the proceeds from the single land tax are distributed as follows in Conakry area: State budget- 20\%; the city budget- $40 \%$ and the municipality's budget- 40\% (LF 2001, Art. 35). 
3.2.3 Some Formulas in a Single Land Tax

$$
\begin{aligned}
& \text { 1) } \mathrm{Tr}=\mathrm{R} / \mathrm{Px} 100 \\
& \mathrm{Tr}=\text { Recovery rate (in \%) } \\
& \mathrm{R}=\text { Recovery } \\
& \mathrm{P}=\text { Forecast } \\
& \text { 2) Top = DP / Px100 } \\
& \mathrm{Tp}=\text { Rate Forecast } \\
& \mathrm{DP}=\text { Projected Deficit } \\
& \mathrm{P}=\text { Forecast }
\end{aligned}
$$

3) For buildings occupied by the owners

$$
\begin{aligned}
& \mathrm{CFU}=10 \% \mathrm{VL} \\
& \mathrm{VL}=\text { Rental Value }
\end{aligned}
$$

4) For rental properties

$$
\begin{aligned}
& \mathrm{CFU}=15 \% \mathrm{VL} \\
& \text { 5) For a company } \\
& \mathrm{VV}=70 \% \text { of TEV } \\
& \mathrm{VL}=10 \% \mathrm{VV} \\
& \mathrm{CFU}=10 \% \text { of } \mathrm{VL} \\
& \mathrm{VL}=\text { Rental Value } \\
& \mathrm{TEV}=\text { Taxable Value of equipment } \\
& \mathrm{VV}=\text { Market Value } \\
& \text { CFU = single land tax }
\end{aligned}
$$

\section{Results and Discussion}

The result of the analysis of taxes and charges collected in the city of Conakry is summarized in the tables (see appendix). It is clear from the tables (1and 2) that the weight of municipalities remains relatively constant from 2005 to 2006. It should be noted in particular that the municipalities of Matam, Ratoma and Kaloum fell slightly in favor of Dixinn and Matoto, the reason is that buildings are concentrated in these three municipalities.

In table 3, the communes Ratoma, Dixinn and Matoto have more interest in a particular investigation of the CFU, the option for some and conurbation for others. The overall rising potential to the CFU, in terms of rental value, realized by the Housing and Rent Survey measures the tax burden on each commune, by nature of taxable property. Reasoning by mass properties (other buildings), the potential of the CFU is distributed as follows: Ratoma, Matam, Dixinn, Matoto and Kaloum. This distribution is more relevant to the extent that it excludes large taxpayers whose tax burden counterbalances the small numbers who are, among others, the Port, BICIGUI Bank, telecommunication company (SOTELGUI) in Kaloum; Airport in Matoto.

From table 4 and Figure 1, it was found that a progressive increase of the achievements of the CFU from 2003 to 2006 made exceptions for the year 2004. The decrease recorded in 2004 is justified by the lack of seriousness, rigor and transparency which resulted in the reluctance of taxpayers whereas significant results for both years are due to the requirements by the Ministry of Economy and Finance on one hand and the involvement of governors on the other.

From the table 5, the collection rate increases from 2003 to 2006 despite the weaknesses mentioned above. This is explained not only by some pressure from the tax on corporations for increased revenue, but also by the remarkable growth of some taxpayers.

From the table 6 and Figure 2, it appears that the voluntary payment of the CFU grew from 2003 to 2004 and then started to decline for the last two years (2005 and 2006). The voluntary payment is greater than that imposed for the simple reason that all companies and businesses subject to the CFU were identified and recognized by tax officials around the code Tax Registration Number NIF (Numéro d'Immatriculation Fiscal). 
It was noted from table 7and Figure 3 that the collection rate of Kaloum commune changed and has ups and downs whose extreme values were encountered in 2005 and 2006 . The rate of $100.15 \%$ in 2005 was achieved through the sacrifices made by the council tax and service whose members were replaced.

Finally, it was found from the table 8 that the communes of Dixinn and Matoto's recorded rate of higher deficit forecasts of the city would be on the one hand, the fact that the forecasts had been minimized and secondly, that the repertoire of taxpayers enrolled and recoveries are not available to the officers or accountants which subtracts a transparent management of revenues.

\section{Analysis of Some Problems of the City of Conakry}

The conceptual framework text on the special status of the city of Conakry and the five municipalities in implementing of the decree recognized the many dysfunctions in the organization and operation that require the need to rethink the framework and the intervention response system of decentralized income tax. In light of these considerations, it's necessary to formulate a summary of problems and proposed solutions.

$$
<\text { Table } 9 \text { about here }>
$$

\section{Conclusion and Suggestions}

In conclusion, it can be said that this study will help in ensuring successful mobilization of local financial resources for development and enable stakeholders to be actively involved in decisions and choices as a means for solving their weaknesses. There are several weaknesses identified by this study in the administration of the CFU in the Conakry Governorate and these can be summarized as: the lack of viable resources for improved forecasting; the reluctance of taxpayers to fulfill their obligations and pay taxes promptly; the level of involvement of local officials in the process of identification and recovery of resources (taxes); the lack of transparency in the allocation of shares or proceeds among the governments; impunity and lack of pressure on taxpayers and imperfect command of taxpayers directories.

Other shortcomings identified included the lack of logistics to conduct the census operations of collection and control, lack of effectiveness of most of those responsible for management as professional offices are not always conscious; misuse of public money by some officials in the tax collection units, lack of motivation of staff, the non-awareness of taxpayers coupled with high levels of illiteracy, among others.

Notwithstanding, there was a multitude of taxable income realized on the basis of this study of the CFU from 2003 to 2006. In 2003, a forecast of $\$ 506,611.10$ was made whereas the recovered amount was $\$ 345,199.29$, reflecting a recovery rate of $65.46 \%$. For the years 2004,2005 and 2006 , the forecasts were $490516.43,647864.73$, and 1147465.94 whereas the recovery rates were $44.91 \%, 97.15 \%$ and $78.30 \%$ respectively. However, there is a lot of room for improvement and even realize more ambitious targets of the forecasts. To achieve this, it's good to think it time to develop and implement appropriate strategies to overcome the factors in social, economic and political spheres and consequences resulting from loss of interest of capital city populations as manifested in low amounts of tax collections. Some of the policies suggested by this study include:

To the state: should ensure the availability of logistical means in order for the officers to properly carry out their mission; the establishment of formal relations between the departments of taxation, the structure of the habitat as part of the location and identification of taxpayers; the improvement in the pace of lending which is not satisfactory because the amounts collected are unknown and this does not allow communities to have an idea of retrocession; strengthening the control and pressure to curb fraud and tax avoidance; the motivation of staff by a gradual increase in wages; the promotion of low-rent apartment projects through bilateral cooperation. The state should also ensure the removal of the governor of Conakry in local tax collection processes to give communities financial autonomy and revision of the tax status of the city; the fiscal independence of communities for better management of receipts; and the introduction of a scan-tax system.

To the officers: make available the directory of articles of enrolled taxpayers and collected taxes to the officials and accountants; and make available to taxation and tax services the statistics to ensure transparency and proper management of resources.

For the locally elected: the promotion of external funding for communities in Conakry through the development of decentralized cooperation; the achievement of concrete actions to fortify the community;

review of forecasting methods of local budgets; and the computerization of statistical data of all departments to ensure continuity in administration. 


\section{References}

Bah, M. S. \& Coll. (2006). Problématique de la Mobilisation des Ressources Financières au Crédit Rural de Guinée S.A centre d'application caisse locale de NAFA de LABE ISAV-VGE/Faranah Rep de Guinée.

Barry, O. (2006). Finances Publiques, ISAV-VGE / Faranah Rep de Guinée.

Basilia Chantal CODJO épse TOVIGNAN(2008). Demarche Participative danns la conduite des actions de développement au Benin: cas de trois communes: Nikki, Boukombe et Cobly, Institut Africain de professionnalisation en management, Ouagadougou, Burkina Faso(Chapter1)

Bernard \& Coll: Dictionnaire Economique et Financier.

Budgets et Comptes administratifs de la ville de Conakry(2006).

Code general impôts (2004). [Online] Available:www.douanesguinee.gov.gn/ordon003.htm

Diagnostique financier du gouvernorat de la ville de Conakry et les cinq(5) communes l'agglomération de conakryPUD3(2003).

Diallo, M. S. K. \& Coll. (2007). Problématique de la Mobilisation des Ressources Financières Locales pour le Développement à a'la base: Cas de La CFU et de la TUV au gouvernorat de la ville de Conakry.

Doumbouya, D. \& Coll. (2006). Problématique de la Mobilisation des Ressources Financières Locales pour le Développement Communautaire à a' la base centre d'application CRD Allassoyah Préfecture de Forécariah ISAV-VGE / Faranah. Rep de Guinée.

Fenu, J. (2006). Capitalisation des expériences des projets d'appui en développement local et décentralisation en Afrique de l'Ouest: Le cas de la Guinée. Fonds d'Équipement des Nations Unies

Final Report Prepared by SITRASS. (2004). International Solidarity on Transport and Research in Sub-Saharan Africa Sub-Saharan Policy Transport Program (SSATP) Africa Region World Bank. Poverty and Urban Mobility in Conakry. Autres publications sur le site Internet du ssatp www.worldbank.org/afr/ssatp

Finances des Collectivités Locales (1999).

Google earth (08/30/2010)

J. Mercoiret cité par Issa SORGHO (2006). Développement local et décentralisation.

Janes, B. (2002). Dictionary of economics. $2^{\text {nd }}$ edition. Oxford University.

Kourouma, B. (2006). Droit Fiscal ISAV-VGE / Faranah, Rep de Guinée.

L'AFD \& le développement local en zones rurales, note d'orientations opérationnelles ; janvier 2001

Le Budget Primitif (2004).

Le Compte Prévisionnel de Gestion (2000) .

Le Guide du Contribuable (1998).

Lenoir, R. (1998). Etude pour une politique de l'habitat en Guinée, Identification et Orientation.

Les Communes de Moins de 10000 Habitants en France (2000PARIS) .

Les Sciences Economiques et Sociales (1990).

Moundekeno, T. B. (2006). Economie de Développement ISAV-VGE / Faranah Rep de Guinée.

N’Diaye, A. (2006). Gestion de Projet, ISAV-VGE / Faranah Rep de Guinée.

Paul Houée cité par Clause Casagrande déc. (2003) ; Rôle des collectivités locales dans le développement local ;

Plan de développement urbain de Conakry Mai 1998) Tomes1 et Tome2

Plan de Développement Urbain de Conakry tomes 1 et 2 (Mai 1988) .

Recueil des textes législatifs et réglementaires en matière des finances publiques volume1 (2004).

Répertoire des Contribuables Direction Nationale des Impôts DNI(Mai 2004).

Richard, A., Tompapa, É. \& Aliou Bah, M. (1998). Conakry, porte de la Guinée, ... ISBN : 978-2-913326-02-6. Éditeur: Ganndal Conakry Edicef Vanves 143p. 
Tagbino, A. S. \& Coll. (2006). Etude de la Dynamique et la Stratégie de la Mobilisation des Ressources Budgétaires des Collectivités Décentralisées: Cas de la Commune Urbaine de Faranah ISAV-VGE de Faranah. Rep de Guinée.

Two United Nations Plaza, 26 Plaza 26th Floor New York, NY 10017 Site web: http: / / www.uncdf.org Courriel:info@uncdf.org.

Vachon, B. (2001). Le développement local intégré : une approche humaniste, économique et écologique du développement des collectivités locales

$\mathrm{Htt}: / /$ wwwxe.com/ucc/convert.cgi

Http://en Wikipedia.org/wiki/file:guinea-map.png

Http://enwikipedia.org/wiki/file:guinea-sat.png

Http://fr.wikipedia.org/wiki/démographie-de-la-guinée

Http://wikipedia.org/wiki/file:guinea-regions.png

Http://www.mirinet.com/gn-env/GN-BREF.html.

Table 1. Determination of share of (CFU) in tax revenues from 2003 to 2006

\begin{tabular}{|c|c|c|c|c|c|c|c|c|}
\hline Years & 2003 & $\begin{array}{c}\text { Rate } \\
(\%)\end{array}$ & 2004 & $\begin{array}{c}\text { Rate } \\
(\%)\end{array}$ & 2005 & $\begin{array}{c}\text { Rate } \\
(\%)\end{array}$ & 2006 & $\begin{array}{c}\text { Rate } \\
(\%)\end{array}$ \\
\hline Tax Revenue & 524993.90 & 100 & 673121.66 & 100 & 717273.24 & 100 & 1150557.54 & 100 \\
\hline CFU & 166551.41 & 31.72 & 152955.28 & 22.72 & 388588.15 & 54.17 & 505731.41 & 43.95 \\
\hline
\end{tabular}

Source: (Investigation 2007).

Table 2. Number of article requested to the CFU per municipalities in 2005 and 2006

\begin{tabular}{|c|c|c|c|c|}
\hline \multirow{2}{*}{ Years } & \multicolumn{2}{|c|}{ Articles 2005 } & \multicolumn{2}{c|}{ Articles 2006 } \\
\cline { 2 - 5 } Commun & Number & $(\%)$ & Number & $(\%)$ \\
\hline Kaloum & 703 & 16.66 & 1519 & 15.05 \\
Dixinn & 771 & 18.26 & 1858 & 18.42 \\
Matam & 787 & 18.66 & 1602 & 15.88 \\
Ratoma & 1180 & 27.98 & 2626 & 26.03 \\
Matoto & 777 & 18.42 & 2484 & 24.62 \\
\hline Conakry (total) & 4218 & 100.00 & 10089 & 100.00 \\
\hline
\end{tabular}

Source: (Investigation 2007) 
Table 3. Estimated Potential Tax at (CFU) 2006

\begin{tabular}{|c|c|c|c|c|c|c|}
\hline \multicolumn{7}{|c|}{ Commune by rental value $(\$)$} \\
\hline Taxable items & Dixinn & Kaloum & Matam & Matoto & Ratoma & Total \\
\hline \multirow{5}{*}{$\begin{array}{l}\text { Real estate } \\
\text {-Activities } \\
\text {-Other built } \\
\text { environments }\end{array}$} & \multirow{3}{*}{32639.27} & 3104012.27 & 683403.68 & \multirow{3}{*}{566465.58} & \multirow{3}{*}{118889.46} & 4505410.27 \\
\hline & & \multirow{4}{*}{$\begin{array}{c}36182.14 \\
1079982.05\end{array}$} & \multirow{4}{*}{$\begin{array}{c}61656.33 \\
1969195.08\end{array}$} & & & 640036.28 \\
\hline & & & & & & \multirow[t]{3}{*}{7578615.77} \\
\hline & 46992.48 & & & 217442.25 & 277762.12 & \\
\hline & 1298219.96 & & & 1070517.48 & 2160795.08 & \\
\hline \multirow{4}{*}{$\begin{array}{l}\text { Diplomatic } \\
\text { Representation } \\
\text { and International } \\
\text { Organization }\end{array}$} & \multirow{4}{*}{$\mathrm{N} / \mathrm{A}$} & \multirow{4}{*}{$\mathrm{N} / \mathrm{A}$} & \multirow{4}{*}{$\mathrm{N} / \mathrm{A}$} & \multirow{4}{*}{$\mathrm{N} / \mathrm{A}$} & \multirow{4}{*}{$\mathrm{N} / \mathrm{A}$} & \multirow{4}{*}{563380.28} \\
\hline & & & & & & \\
\hline & & & & & & \\
\hline & & & & & & \\
\hline \multirow[t]{2}{*}{ Built Heritage } & \multirow[t]{2}{*}{$\mathrm{N} / \mathrm{A}$} & \multirow[t]{2}{*}{ N/A } & \multirow[t]{2}{*}{$\mathrm{N} / \mathrm{A}$} & \multirow[t]{2}{*}{$\mathrm{N} / \mathrm{A}$} & \multirow[t]{2}{*}{$\mathrm{N} / \mathrm{A}$} & \\
\hline & & & & & & 45070.42 \\
\hline Total & 1377851.72 & 4220176.47 & 271425.11 & 1854425.31 & 2557446.66 & 13332605.99 \\
\hline \multirow[t]{2}{*}{ Possible forecasting } & \multirow[t]{2}{*}{$\mathrm{N} / \mathrm{A}$} & \multirow[t]{2}{*}{$\mathrm{N} / \mathrm{A}$} & \multirow[t]{2}{*}{$\mathrm{N} / \mathrm{A}$} & \multirow[t]{2}{*}{$\mathrm{N} / \mathrm{A}$} & \multirow[t]{2}{*}{$\mathrm{N} / \mathrm{A}$} & \\
\hline & & & & & & 1799901.81 \\
\hline
\end{tabular}

Source: (Investigation 2000);

Table 4. Status of CFU from 2003 to 2006 for the city of Conakry

\begin{tabular}{|c|c|c|c|}
\hline Year & Forecast $(\$)$ & Collection $(\$)$ & Rate of collection $(\%)$ \\
\hline 2003 & 93896.71 & 61885.07 & 65.90 \\
\hline 2004 & 150234.74 & 44014.15 & 29.29 \\
\hline 2005 & 159624.41 & 149353.37 & 93.56 \\
\hline 2006 & 469483.56 & 419695.42 & 89.39 \\
\hline Total & 873239.43 & 674948.03 & 77.29 \\
\hline
\end{tabular}

Source: (Investigation 2007)

Table 5. The moral situation of the CFU for the city of Conakry (2003-2006)

\begin{tabular}{|c|c|c|c|c|}
\hline Years & Forecast $(\$)$ & Issue $(\$)$ & collection $(\$)$ & Collection Rate $(\%)$ \\
\hline 2003 & 845070.42 & 746208.39 & 167284.31 & 22.41 \\
\hline 2004 & 929577.46 & 870408.30 & 436235.82 & 50.11 \\
\hline 2005 & 938967.13 & 977747.80 & 506484.65 & 51.80 \\
\hline 2006 & 1126760.56 & 952105.13 & 566366.89 & 59.48 \\
\hline Total & 3840375.58 & 3546469.64 & 1676371.68 & 47.27 \\
\hline
\end{tabular}

Source: (Investigation 2007) 
Table 6. Comparison of changes in collection methods

\begin{tabular}{|c|c|c|c|c|c|c|c|c|}
\hline Companies & 2003 & & 2004 & & 2005 & & 2006 & \\
\cline { 2 - 9 } & Total & $\%$ & Total & $\%$ & Total & $\%$ & Total & $\%$ \\
\hline $\begin{array}{c}\text { Withholding } \\
\text { rent (RSL) }\end{array}$ & 101 & 62.73 & 164 & 70.38 & 129 & 66.83 & 101 & 62.73 \\
\hline $\begin{array}{c}\text { Tax notice } \\
\text { (AIM) }\end{array}$ & 60 & 37.27 & 69 & 29.62 & 64 & 33.17 & 60 & 37.27 \\
\hline Total & 161 & 100.00 & 233 & 100.00 & 193 & 100.00 & 161 & 100.00 \\
\hline
\end{tabular}

Source: (Investigation 2007)

(RSL): Retenue à la source

(AIM): Avis d'imposition

Table 7. Status of CFU for the municipalities of KALOUM

\begin{tabular}{|l|c|c|c|}
\hline Years & Forecast $(\$)$ & Collection(\$) & Collection Rate(\%) \\
\hline 2003 & 77076.76 & 61206.53 & 79.40 \\
\hline 2004 & 100161.66 & 48399.60 & 48.32 \\
\hline 2005 & 137793.70 & 138004.97 & 100.00 \\
\hline 2006 & 196306.94 & 169315.33 & 86.25 \\
\hline
\end{tabular}

Source: (Investigation 2007)

Table 8. Comparison of Forecast for the Year 2006 compared to the Possible forecast (the survey)

\begin{tabular}{|c|c|c|c|c|c|}
\hline Cormunties Forcast & Dixinn & Kaloum & Matam & Matoto & Total \\
\hline Forecast & 35305.16 & 196306.94 & 112676.05 & 48248.20 & 392536.36 \\
\hline possible Forecast & 186009.98 & 569723.82 & 366424.43 & 250347.41 & 1372505.66 \\
\hline Projected deficit & 150704.81 & 373416.88 & 253748.38 & 202099.21 & 979969.29 \\
\hline Rate(\%) & 426.86 & 190.22 & 225.20 & 418.87 & 249.65 \\
\hline
\end{tabular}

Source: (Investigation2007) 
Table 9.

\begin{tabular}{|c|c|c|c|}
\hline Problems & Causes & Consequences & Proposed solution \\
\hline $\begin{array}{l}\text {-Strong } \\
\text { involvement of the } \\
\text { non-paid official in } \\
\text { the census } \\
\text { operations and } \\
\text { collection }\end{array}$ & $\begin{array}{l}\text { - Contracts that bind } \\
\text { communities such personnel do } \\
\text { not take the form and spirit of } \\
\text { the labor code which they } \\
\text { comes under the control }\end{array}$ & $\begin{array}{l}\text { - Trafficking } \\
\text { avoidance, } \\
\text { embezzlement. }\end{array}$ & $\begin{array}{l}\text {-Rehabilitate labor contracts } \\
\text { according to the Labor Code. } \\
\text {-Valuing-wage of contract } \\
\text { workers } \\
\text {-Ensure their coverage }\end{array}$ \\
\hline $\begin{array}{l}- \text {-The imperfect } \\
\text { command of } \\
\text { taxpayers } \\
\text { directories }\end{array}$ & $\begin{array}{l}\text {-The lack of tools and supports } \\
\text { (plot plan, addressing plan). }\end{array}$ & $\begin{array}{l}\text {-Under-estimate } \text { of } \\
\text { potential tax. }\end{array}$ & $\begin{array}{l}\text {-Ensure subdivision } \\
\text {-The establishment of addressing' } \\
\text { plan }\end{array}$ \\
\hline $\begin{array}{lr}\text { Tax } & \text { fraud } \\
\text { orchestrated } & \text { by } \\
\text { collectors. } & \end{array}$ & $\begin{array}{l}\text {-Payment in cash. } \\
\text {-The high number of agents per } \\
\text { tax collection team }\end{array}$ & $\begin{array}{l}\text {-Determination of tax } \\
\text { payment }\end{array}$ & $\begin{array}{l}\text {-By bank check payable to } \\
\text { non-enforceable the tax collector } \\
\text { when the amount exceeds } \$ 10 \text {. }\end{array}$ \\
\hline $\begin{array}{l}\text {-The formalization } \\
\text { of non-lease }\end{array}$ & $\begin{array}{l}\text {-Illiteracy } \\
\text {-Nomadism of landlords } \\
\text {-The absence of low-rent } \\
\text { apartment }\end{array}$ & $\begin{array}{ll}\quad \text { Difficulties } & \text { of } \\
\text { census - } & \\
\text { liquidation } & \text { and } \\
\text { collection } & \end{array}$ & $\begin{array}{l}\text {-Promote awareness campaign for } \\
\text { taxpayers } \\
\text {-Encourage donors to housing } \\
\text { construction projects }\end{array}$ \\
\hline $\begin{array}{l}\text {-The absence of } \\
\text { fiscal command by } \\
\text { collectivities. }\end{array}$ & $\begin{array}{l}\text {-Lack of information and } \\
\text { transparency. }\end{array}$ & $\begin{array}{l}\text {-The low rates of } \\
\text { collection }\end{array}$ & $\begin{array}{l}\text {-To inform local officials in the } \\
\text { process of mobilization and } \\
\text { management of tax revenues. }\end{array}$ \\
\hline $\begin{array}{l}\text {-Lack of statistical } \\
\text { data at the } \\
\text { community level } \\
\text { and tax services. }\end{array}$ & $\begin{array}{l}\text { Non computerization of } \\
\text { existing data. - The unreliability } \\
\text { of collection }\end{array}$ & $\begin{array}{l}\text {-Discontinuity of the } \\
\text { tax administration } \\
\text {-Lack of access to } \\
\text { data. }\end{array}$ & $\begin{array}{l}\text {-To make a complete census. } \\
\text {-Computerized statistical data to } \\
\text { ensure continuity } \\
\text { administration. }\end{array}$ \\
\hline $\begin{array}{ll}\text {-The absence } & \text { of } \\
\text { pressure } & \text { on } \\
\text { delinquent } & \\
\text { taxpayers } & \end{array}$ & $\begin{array}{l}\text {-Carelessness; laissez-faire } \\
\text { caused by authorities }\end{array}$ & $\begin{array}{l}\text {-Reluctance } \\
\text { taxpayers. }\end{array}$ & $\begin{array}{l}\text { - Apply the principles and laws } \\
\text { relating to taxes }\end{array}$ \\
\hline $\begin{array}{l}\text {-Unsatisfactory } \\
\text { pace } \\
\text { retrocession }\end{array}$ & $\begin{array}{l}\text {-Lack of transparency in the } \\
\text { process of retrocession } \\
\text {-The lack of knowledge by } \\
\text { collectivities the collected } \\
\text { amount in taxes }\end{array}$ & $\begin{array}{l}\text {-The imbalance of } \\
\text { reassigned amount at } \\
\text { collectivity level. }\end{array}$ & $\begin{array}{l}\text {-Involve local elected officials in } \\
\text { the handover process. }\end{array}$ \\
\hline $\begin{array}{l}\text {-Weak } \\
\text { embarrassing and } \\
\text { unjustifiable } \\
\text { resources } \\
\text { commercial of } \\
\text { facilities }\end{array}$ & $\begin{array}{l}\text { - Operation of this facility in } \\
\text { conditions devoid of all notions } \\
\text { of profitability } \\
\text {-The total control by the } \\
\text { government. }\end{array}$ & $\begin{array}{l}\text {-Weak receipts from } \\
\text { these facilities }\end{array}$ & $\begin{array}{l}\text {-Return the facilities to their } \\
\text { municipalities of origins }\end{array}$ \\
\hline $\begin{array}{l}\text {-The influence of } \\
\text { certain } \quad \text { senior } \\
\text { executives } \\
\text { Directors }\end{array}$ & $\begin{array}{l}\text {-Confidence in themselves for } \\
\text { their administrative affiliation } \\
\text { (Headquarters, Justice, } \\
\text { Presidency) }\end{array}$ & $\begin{array}{ll}\text {-Non-payment } & \text { of } \\
\text { certain taxpayers in } \\
\text { CFU. }\end{array}$ & $\begin{array}{l}\text {-Apply the regulations without } \\
\text { distinction }\end{array}$ \\
\hline
\end{tabular}


Table 10. The collection of the CFU ongoing for the city of Conakry

\begin{tabular}{|c|c|}
\hline Periods & Collection CFU morale \\
\hline From 1 to March 31 & N/A \\
From April 25 to 30 & 14694.91 \\
From May 1 to 7 & 16197.18 \\
From May 8 to 14 & 18262.83 \\
From May 15 to 21 & 7666.79 \\
From May 22 to 28 & 9349.76 \\
\hline Total & 61101.44 \\
\hline
\end{tabular}

Source: (Investigation 2007)

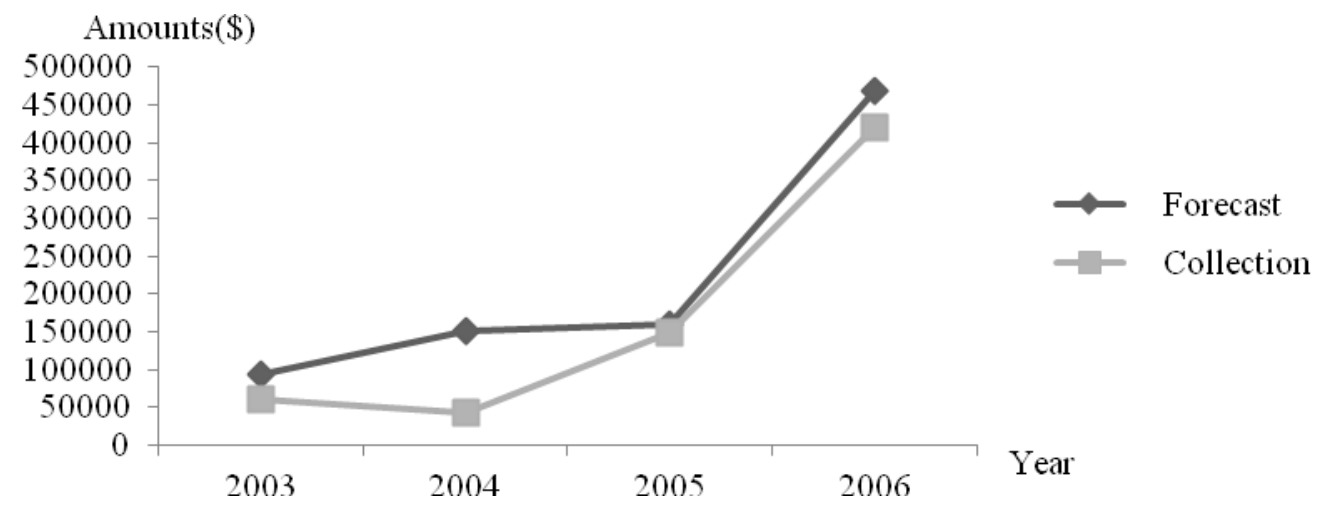

Figure 1. Evolution of forecasts and Collection in CFU of Conakry city

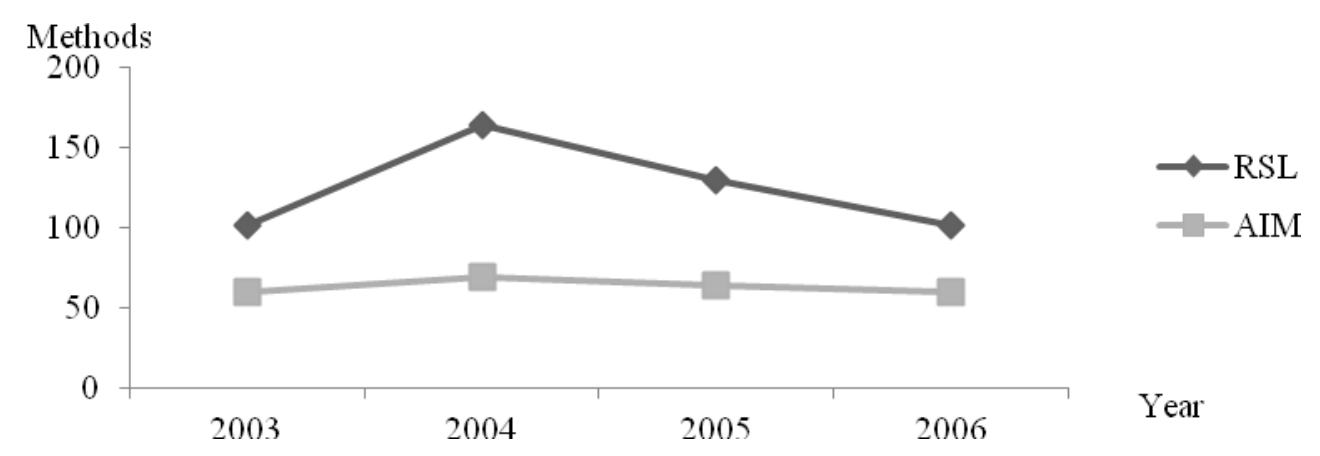

Figure 2. Comparison of the evolution of the two methods of recovery 


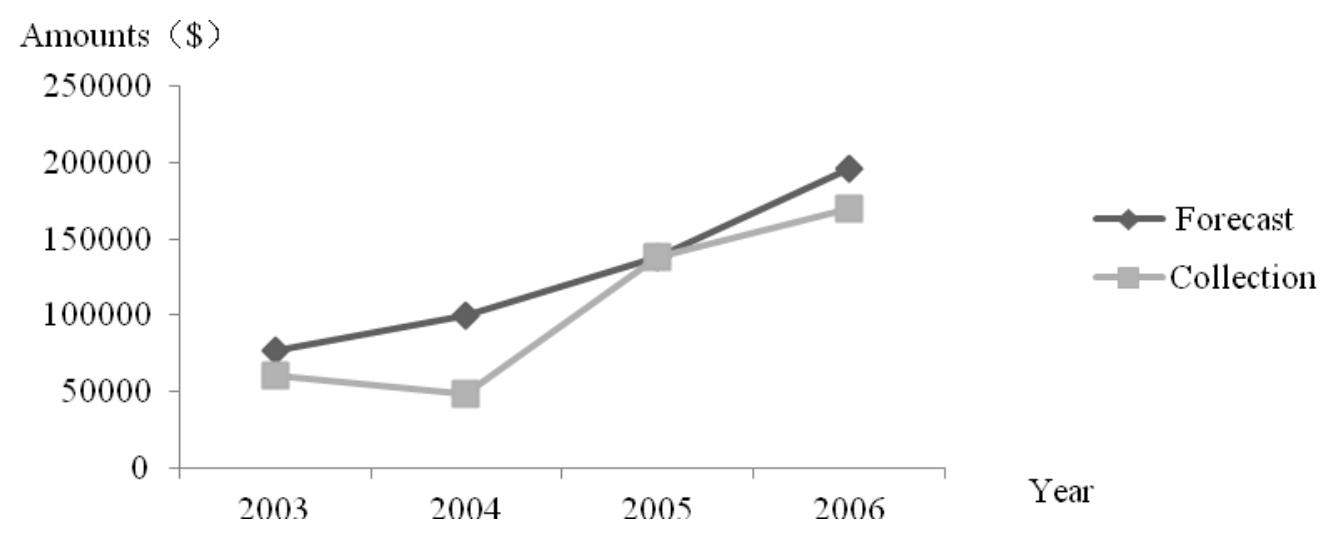

Figure 3. Trends of Forecasts and collection in KALOU

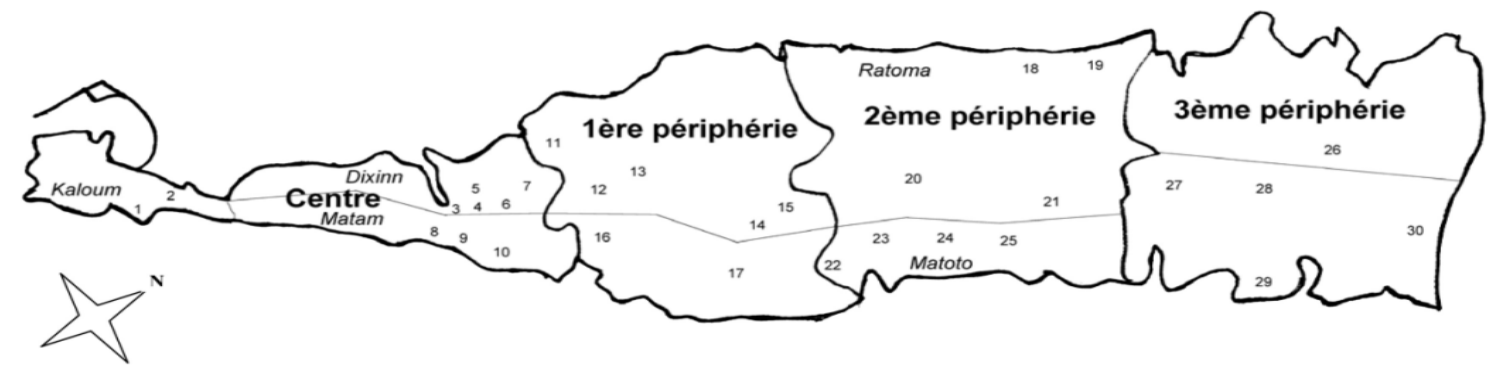

Figure 4. (Conakry) location of the quantitative household survey areas 